OPEN ACCESS

Edited by:

Hajo Zeeb,

Leibniz Institute for Prevention Research and Epidemiology (LG),

Germany

Reviewed by:

Fiona Baine-Savanhu,

University of the Witwatersrand,

South Africa

*Correspondence:

Rokhaya Ndiaye

rokhaya9.ndiaye@ucad.edu.sn

Specialty section:

This article was submitted to

Cancer Epidemiology and Prevention, a section of the journal

Frontiers in Oncology

Received: 05 November 2021

Accepted: 07 December 2021

Published: 13 January 2022

Citation:

Diop JPD, Sène ARG, Dia Y,

Ba SA, Mbacke SS, Ly CAT,

Sarr PD, Diouf D, Ka S, Mbengue $B$, Gueye SMK, Diop PS, Sylla Niang M,

Gueye PM, Lopez Sall P, Dem A,

Cisse A, Dieye A and Ndiaye $R$ (2022) New Insights Into C.815 824dup

Pathogenic Variant of BRCA1 in Inherited Breast Cancer: A Founder Mutation of West African Origin.

Front. Oncol. 11:810060. doi: 10.3389/fonc.2021.810060

\section{New Insights Into c.815_824dup Pathogenic Variant of BRCA1 in Inherited Breast Cancer: A Founder Mutation of West African Origin}

\author{
Jean Pascal Demba Diop ${ }^{1}$, Andréa Régina Gnilane Sène ${ }^{1}$, Yacouba Dia ${ }^{1}$, \\ Seydi Abdoul Ba ${ }^{1}$, Serigne Saliou Mbacke ${ }^{1}$, Cheikh Ameth Tidiane $\mathrm{Ly}^{1}$, Pierre Diaga Sarr ${ }^{1}$, \\ Doudou Diouf ${ }^{2}$, Sidy Ka ${ }^{2}$, Babacar Mbengue ${ }^{3}$, Serigne Modou Kane Gueye ${ }^{4}$, \\ Pape Saloum Diop ${ }^{5}$, Maguette Sylla Niang ${ }^{3}$, Papa Madieye Gueye ${ }^{6}$, Philomene Lopez Sall ${ }^{6}$, \\ Ahmadou Dem ${ }^{2}$, Aynina Cisse ${ }^{6}$, Alioune Dieye ${ }^{3}$ and Rokhaya Ndiaye ${ }^{1 *}$ \\ ${ }^{1}$ Division of Human Genetics, Faculty of Medicine, Pharmacy and Odontology, University Cheikh Anta Diop (UCAD), Dakar, \\ Senegal, 2 Joliot Curie Institute, Aristide Le Dantec Hospital, Dakar, Senegal, ${ }^{3}$ Immunology Unit, Faculty of Medicine, Pharmacy \\ and Odontology, University Cheikh Anta Diop (UCAD), Dakar, Senegal, ${ }^{4}$ Gynecology Unit, Aristide Le Dantec Hospital, \\ Dakar, Senegal, ${ }^{5}$ Unit of General Surgery, General Hospital Idrissa Pouye, Dakar, Senegal, ${ }^{6}$ Laboratory of Pharmaceutical \\ Biochemistry, Faculty of Medicine, Pharmacy and Odontology, University Cheikh Anta Diop (UCAD), Dakar, Senegal
}

Founder mutations have been reported in BRCA1 and BCRA2 in different ethnic groups with inherited breast cancer. Testing of targeted mutations in specific populations is important for cancer prevention in mutation carriers. In Sub-Saharan Africa, only a few studies have reported specific founder mutations in inherited breast cancer. The pathogenic variant c.815_824dup of BRCA1 has been reported as the most frequent among African American populations with inherited breast cancer and was supposed to have a West African origin. Recent report from Senegal identified this variant in women with inherited breast cancer at the highest frequency ever reported. The variant was linked to a common haplotype confirming its founder effect in West Africa. In this article, we review the mutation history of c.815_824dup and discuss how it spread out of Africa through the transatlantic slave trade.

Keywords: inherited breast cancer, BRCA1 gene, pathogenic variant, founder mutation, Africa

\section{INTRODUCTION}

About $5 \%-10 \%$ of breast cancer cases are associated with inherited susceptibility. A subset of these are linked to germline pathogenic variants in BRCA1 and BRCA2 tumor suppressor genes (1). Women who have inherited the BRCA1 or the BRCA2 mutation are at greater risk of developing breast and/or ovarian cancer $(2,3)$. Studies in different populations have identified pathogenic variants stored in BRCA mutation consortia databases: CIMBA (Consortium of Investigators of Modifiers of BRCA1/2), ENIGMA (Evidence-Based Network for the Interpretation of Germline Mutant Alleles), BRCA Share (formerly the UMD-BRCA1 mutations database), and BRCA Exchange (https://brcaexchange.org). Some of these variants are at very high frequencies in specific ethnic groups, suggesting their founding effect. In Sub-Saharan Africa, a few studies have 
reported specific founder mutations $(4,5)$. Recently, we have reported a founder mutation, c.815_824dup, of the BRCA1 gene in Senegalese women with inherited breast cancer (6). This mutation is a duplication of 10 nucleotides (c.815_824dupAGCCATGTGG, p.Thr276AfsX14) located in exon 11 of BRCA1 according to the Human Genome Variation Society (HGVS) nomenclature and leads to a frameshift and a truncated protein. A previous study on African American women has reported the variant as a founder mutation of West African Origin (7).

\section{HISTORY OF THE C.815_824DUP BRCA1 PATHOGENIC VARIANT}

Review from the literature has shown that c.815_824dup was first described in 1997 in a breast cancer patient from the Ivory Coast living in the US who had a familial history of breast, ovarian, and prostate cancers (8). In 1999, Mefford et al. identified the variant in four other families of African origin: one from the Bahamas and three in the US (South Carolina, Florida, and Washington, DC) (7). It was suggested that the variant may be an ancient West African founder mutation (7). Thereafter, the variant was reported in other African admixture populations with inherited breast cancer throughout the world (Bahamas, Peru, Mexico, France, Spain, and North America) (9-17). Literature search showed that the variant has been reported in 23 studies (Table 1). A review by Friebel et al. (31) revealed that the c.815_824dup pathogenic variant was detected in 76 individuals from the CIMBA database, 34 individuals from the Breast Cancer Information Core (BIC) database, and 16 individuals from ClinVar. Overall, the variant was identified in 155 patients. Of these, 100 were self-reported African ancestry (SRAA): 46 African American, 2 African (from Senegal), 6 Caribbean, and 46 of other African descent (31). The allelic frequency of the variant was estimated among African American women with inherited breast cancer at $16 \%$ in 2018 (15) and at 12\% in 2020 (18).

\section{BRCA1 C.815_824DUP PATHOGENIC VARIANT IN AFRICA}

In Africa, until October 2021, only one study from our team has reported the variant in patients diagnosed with inherited breast cancer (6). The variant was identified in 15 index cases with a family history of breast and/or ovarian cancer, out of 27 recruited. Allelic frequency was estimated at $27.7 \%$ compared to sporadic breast cancer cases (5\%) and healthy controls $(0.55 \%)$ (6). We have then implemented in our laboratory a PCR genotyping method of the variant for oncogenetic counseling. Screening of the variant in 19 other index cases with a family history of breast cancer identified the variant in heterozygous state in 11 cases. The variant was also found in 8 out of 36 patients diagnosed without a known family history of breast cancer at under 50 years of age (allelic frequency estimated at $11.11 \%)$. These data strongly support the implication of the variant in inherited breast cancer.
Overall, the c.815_824dup variant was identified in 26 families out of 46 (allelic frequency estimated at 28.26\%). Screening of the variant in healthy relatives also identified the variant in 13 out of 29, confirming its implication in disease etiology. This is the highest frequency of this variant ever reported in a population. The allelic frequency of c.815_824dup is rarely documented throughout the different BRCA variant databases. Available information is from gnomAD and TopMed, where frequencies were estimated at $2.09726 \times 10^{-5}$ and $7.15273 \times 10^{-5}$, respectively, worldwide and in the African population. Other databases revealed the presence of this variant in individuals with African origin [Allele Frequency Aggregator (ALFA), CIMBA, ClinVar, and BIC databases], while any allelic frequency was documented. Larger studies in African countries are needed to estimate the exact allelic frequency of the variant among the African population.

\section{WEST AFRICAN ORIGIN OF BRCA1 C.815_824DUP}

Haplotype analysis of seven microsatellite markers flanking the $B R C A 1$ gene and distributed in $2.15 \mathrm{Mb}$ has identified a common haplotype of $\sim 400 \mathrm{~kb}$ in Senegalese patients. This haplotype was not observed in any of the 48 healthy controls studied and is shorter than the one reported among African Americans spanning $700 \mathrm{~kb}$ (6). Age estimation of the Senegalese haplotype was 1,400 years, while it was 200 years in the US (7). Subsequently, we hypothesized that the variant appeared first in West Africa and spread throughout the world by population migration.

\section{DISCUSSION}

Founder mutations linked to inherited breast cancer have been reported in BRCA1 and BRCA2 genes in different populations. The most known is the Ashkenazi Jewish pathogenic variant c.66_67AG (p.Glu23fs) reported in the US, Europe, Asia, and among Afrikaners from South Africa, while it was not reported in Sub-Saharan Africa, where other mutations have been identified $(15,26)$. In Northern Africa, a few founder mutations have been linked to inherited breast cancer: c.5309G>T (p.Gly1770Val) reported in five unrelated Moroccan families (32) and c.5335delC (p.Gln1779Asnfs) reported in Egypt (33). In Sub-Saharan Africa, the most frequent founder mutations linked to inherited breast cancer are c.303T $>\mathrm{G}$ (p.Tyr101Ter), reported in 4 out of 434 patients in Nigeria (5); c.2641G>T (p.Glu881Ter), identified in 5 patients out of 90 in South Africa (4); and c.815_824dup, identified in 26 out of 46 Senegalese families (6). The high allelic frequency of the c.815_824dup variant (28.26\%) combined with the common haplotype observed in patients bearing the mutation suggested a founder effect in West Africa. Studies from Nigeria and Burkina Faso have not reported the variant in inherited breast cancer cases $(5,34)$. Then, it is actually of interest to screen the variant in other West African countries, particularly those located along the coast such as Ghana, Guinea-Bissau, Benin, Ivory Coast, Guinea, Togo, 
TABLE 1 | Studies reporting the c.815_824dup pathogenic variant throughout the world.

\begin{tabular}{|c|c|c|c|c|c|c|}
\hline Region & Title & Authors & Year & Country & $\begin{array}{l}\text { Number of } \\
\text { patients with } \\
\text { the mutation/ } \\
\text { Allelic } \\
\text { frequency }\end{array}$ & Link to the article \\
\hline Africa & $\begin{array}{l}\text { Evidence for an ancient BRCA1 pathogenic variant in } \\
\text { inherited breast cancer patients from Senegal }\end{array}$ & Ndiaye et al. (6) & 2020 & Senegal & $27.7 \%$ & doi: 10.1038/s41525-020-0114-7 \\
\hline \multirow[t]{14}{*}{ USA } & $\begin{array}{l}\text { Contribution of germline mutations in cancer } \\
\text { predisposition genes to tumor etiology in young women } \\
\text { diagnosed with invasive breast cancer }\end{array}$ & Palmer et al. (18) & 2020 & USA & $12 \%$ & doi: 10.1093/jnci/djaa040 \\
\hline & $\begin{array}{l}\text { Mutational spectrum in a worldwide study of } 29,700 \\
\text { families with BRCA1 or BRCA2 mutations }\end{array}$ & Rebeck et al. (15) & 2018 & USA & $16 \%$ & doi: 10.1002/humu.23406 \\
\hline & $\begin{array}{l}\text { Contribution of Germline Predisposition Gene Mutations } \\
\text { to Breast Cancer Risk in African American Women }\end{array}$ & Rummel et al. (19) & 2017 & USA & 1 & doi: 10.1007/s10549-017-4291-8 \\
\hline & $\begin{array}{l}\text { A high frequency of BRCA mutations in young black } \\
\text { women with breast cancer residing in Florida }\end{array}$ & Pal et al. (20) & 2015 & USA & 2 & doi: 10.1002/cncr.29645 \\
\hline & $\begin{array}{l}\text { Deleterious BRCA1/2 mutations in an urban population } \\
\text { of Black women }\end{array}$ & Lynce et al. (21) & 2015 & USA & 1 & doi: 10.1007/s10549-015-3527-8 \\
\hline & $\begin{array}{l}\text { Inherited predisposition to breast cancer among African } \\
\text { American women }\end{array}$ & Churpek et al. (22) & 2014 & USA & 2 & doi: $10.1007 / s 10549-014-3195-0$ \\
\hline & $\begin{array}{l}\text { Evaluation of BRCA1 mutations in an unselected patient } \\
\text { population with triple-negative breast cancer }\end{array}$ & Rummel et al. (23) & 2013 & USA & 1 & doi: 10.1007/s10549-012-2348-2 \\
\hline & $\begin{array}{l}\text { Recurrent BRCA1 and BRCA2 mutations in breast } \\
\text { cancer patients of African ancestry. }\end{array}$ & Zhang et al. (24) & 2012 & USA & 2 & doi: 10.1007/s10549-012-2136-z \\
\hline & $\begin{array}{l}\text { Earlier age of onset of BRCA mutation-related cancers in } \\
\text { subsequent generations. }\end{array}$ & Litton et al. (25) & 2012 & USA & 1 & doi: 10.1002/cncr.26284 \\
\hline & $\begin{array}{l}\text { BRCA1 and BRCA2 mutations in women of different } \\
\text { ethnicities undergoing testing for hereditary breast- } \\
\text { ovarian cancer. }\end{array}$ & Hall et al. (26) & 2009 & USA & 28 & doi: 10.1002/cncr.24200 \\
\hline & $\begin{array}{l}\text { Prevalence of pathogenic BRCA1 mutation carriers in } 5 \\
\text { US racial/ethnic groups }\end{array}$ & John et al. (27) & 2007 & USA & 1 & doi: 10.1001/jama.298.24.2869 \\
\hline & $\begin{array}{l}\text { Genetic testing in an ethnically diverse cohort of high-risk } \\
\text { women: a comparative analysis of BRCA1 and BRCA2 } \\
\text { mutations in American families of European and African } \\
\text { ancestry }\end{array}$ & Nanda et al. (28) & 2005 & USA & 1 & doi: 10.1001/jama.294.15.1925 \\
\hline & $\begin{array}{l}\text { BRCA1 and BRCA2 Mutations in a Study of African } \\
\text { American breast cancer patients } \\
\text { American Breast Cancer Patients }\end{array}$ & Pal et al. (29) & 2004 & USA & 1 & PMID: 15533909 \\
\hline & Breast cancer genetics in African Americans & Olopade et al. (16) & 2003 & USA & 3 & doi: 10.1002/cncr.11019 \\
\hline \multirow[t]{7}{*}{$\begin{array}{l}\text { Latino- } \\
\text { America }\end{array}$} & $\begin{array}{l}\text { Evidence for a BRCA1 founder mutation in families of } \\
\text { West African ancestry. }\end{array}$ & Mefford et al. (7) & 1999 & $\begin{array}{l}\text { Bahamas US } \\
\text { (South } \\
\text { Carolina, } \\
\text { Florida and } \\
\text { Washington } \\
\text { DC) }\end{array}$ & 5 & doi: 10.1086/302511 \\
\hline & $\begin{array}{l}\text { Mutational analysis of BRCA1 and BRCA2 genes in } \\
\text { Peruvian families with hereditary breast and ovarian } \\
\text { cancer }\end{array}$ & Buleje et al. (30) & 2017 & Peru & 1 & doi: 10.1002/mgg3.301 \\
\hline & $\begin{array}{l}\text { The prevalence of BRCA1 and BRCA2 mutations among } \\
\text { young Mexican women with triple-negative breast } \\
\text { cancer }\end{array}$ & Garza et al. (10) & 2015 & Mexico & 5 & doi: 10.1007/s10549-015-3312-8 \\
\hline & $\begin{array}{l}\text { Prevalence of BRCA1 and BRCA2 mutations in } \\
\text { unselected breast cancer patients from Peru }\end{array}$ & Abugattas et al. (9) & 2015 & Peru & 1 & doi: 10.1111/cge.12505 \\
\hline & $\begin{array}{l}\text { The spectrum of BRCA1 and BRCA2 mutations in } \\
\text { breast cancer patients in the Bahamas }\end{array}$ & Akbari et al. (14) & 2014 & Bahamas & 3 & doi: 10.1111/cge.12132 \\
\hline & $\begin{array}{l}\text { A high prevalence of BRCA1 mutations among breast } \\
\text { cancer patients from the Bahamas }\end{array}$ & $\begin{array}{l}\text { Donenberg et al. } \\
(11)\end{array}$ & 2011 & Bahamas & 3 & doi: 10.1007/s10549-010-1156-9 \\
\hline & $\begin{array}{l}\text { Prevalence of BRCA mutations and founder effect in } \\
\text { high-risk Hispanic families }\end{array}$ & Weitzel et al. (12) & 2005 & Mexico & 1 & $\begin{array}{l}\text { doi: 10.1158/1055-9965.EPI-05- } \\
0072\end{array}$ \\
\hline
\end{tabular}

Sierra Leone, Liberia, and The Gambia. It would also be of interest to screen other neighboring countries to Senegal, such as Mali and Burkina Faso, where slaves have been deported toward West African coasts. From these countries, three played a key role in the transatlantic slave trade during the 18th century. The Senegal, Ghana, and Benin borders served as departure ports of slaves from Africa to the US, the Caribbean, and Europe. Since the distribution of the BRCA1 c.815_824dup variant around the world overlapped 


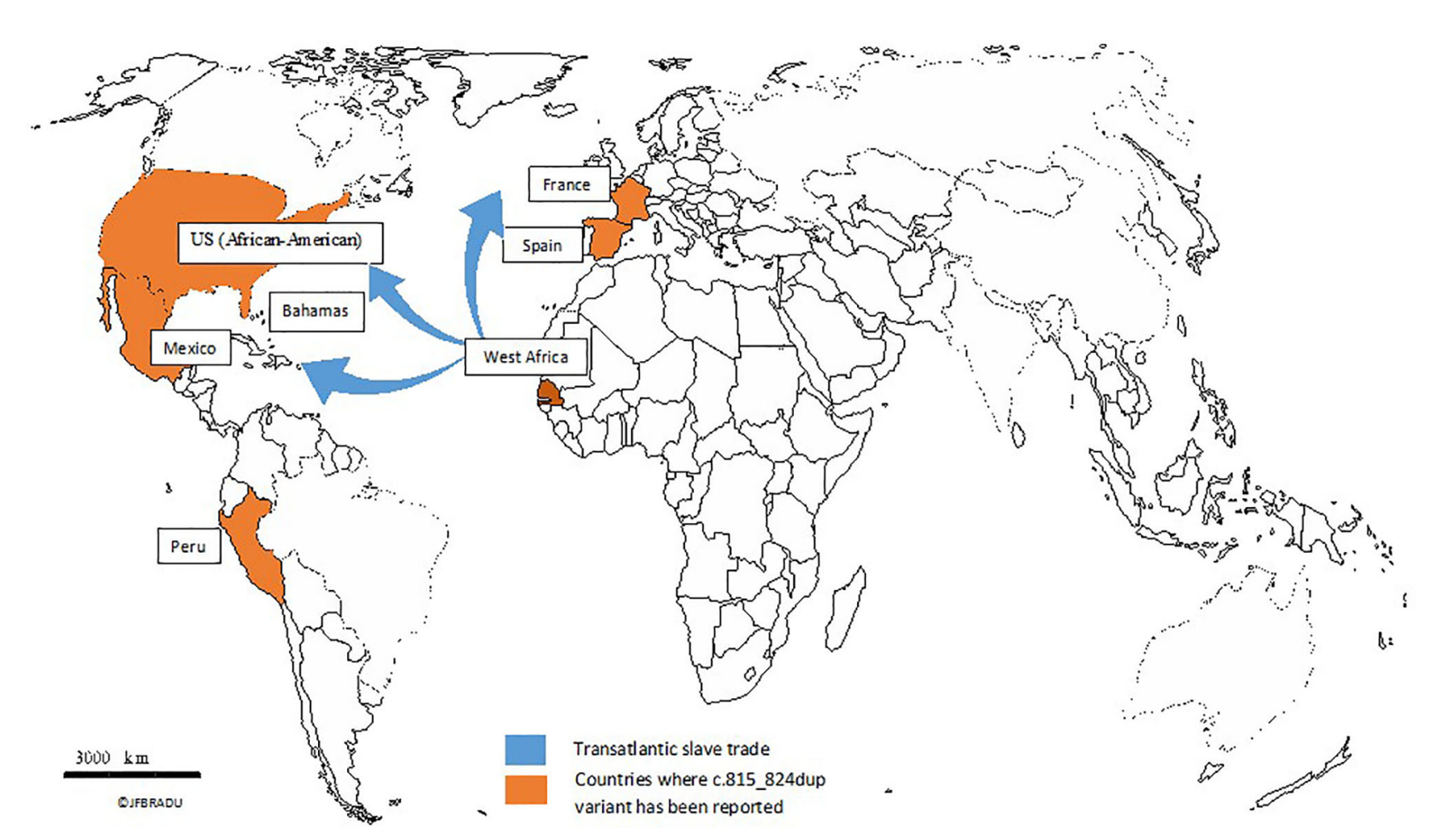

FIGURE 1 | Distribution of the BRCA1 c.815_824dup variant through the transatlantic slave trade from West Africa to other continents.

black population migration, we have hypothesized that the variant first appeared in West Africa and spread out to the other continents (Figure 1). The high frequency of the variant among African Americans (18) and Hispanic people living in the Caribbean and Europe $(13,31)$, the African descent status of people harboring the variant through genomic databases, and the shorter single haplotype observed in Senegalese patients (6) all together support the African founding effect of c.815_824dup. The variant has spread out from Africa to other continents essentially through the transatlantic slave trade. Screening in other African countries may also highlight the implication of the transcontinental slave trade in the distribution of the variant across Africa.

$B R C A 1$ mutations have also been involved in the occurrence of other cancers, including prostate and pancreatic cancer. The c.815_824dup variant has been associated with a risk up to $16 \%$ in prostate cancer and $1 \%$ in pancreatic cancer at age 70 years, according to clinical genetic testing reports from the Myriad Genetics Laboratories. Results from our study also showed, in two index case carriers, male relatives diagnosed with pancreatic/ prostate cancer. Hence, it will be of interest to screen the mutation in Senegalese patients with these cancers in order to evaluate the burden of this mutation in the Senegalese population.

Founder mutations are useful for disease prevention since genetic testing can be targeted. In low-income settings, this will allow more rapid and less expensive testing and enable risk assessment and medical follow-up of people at risk. Studies focusing on a cohort of individuals with the same mutation will also be of interest to identify factors affecting penetrance, phenotype variability, or environmental risk modifiers for a better follow-up of affected individuals.

\section{AUTHOR CONTRIBUTIONS}

JD, RN, AS, YD, SB, SM, CL, and PDS drafted the manuscript. $\mathrm{DD}, \mathrm{SK}, \mathrm{BM}, \mathrm{SG}, \mathrm{PD}, \mathrm{MN}, \mathrm{PG}, \mathrm{PLS}, \mathrm{ADe}, \mathrm{AC}$, and $\mathrm{ADi}$ gave advise on drafting the manuscript. All authors contributed to the article and approved the submitted version.

\section{FUNDING}

This research project was funded by the Ministry of Higher Education and Research of the Republic of Senegal through the 2015 FIRST program.

\section{ACKNOWLEDGMENTS}

We thank all families who agreed to participate in this study. We also thank the staff of the Joliot Curie Institute in Dakar, the Laboratory of Molecular Oncogenetics of the Paoli-Calmette Institute at Marseille, and the Senegalese Ministry of Higher Education and Research who funded the research project. 


\section{REFERENCES}

1. Fackenthal JD, Sveen L, Gao Q, Kohlmeir EK, Adebamowo C, Ogundiran TO, et al. Complete Allelic Analysis of BRCA1 and BRCA2 Variants in Young Nigerian Breast Cancer Patients. J Med Genet (2005) 42(3):276-81. doi: 10.1136/jmg.2004.020446

2. Miki Y, Swensen J, Shattuck-Eidens D, Futreal PA, Harshman K, Tavtigian S, et al. A Strong Candidate for the Breast and Ovarian Cancer Susceptibility Gene Brcal. Science (1994) 266(5182):66-71. doi: 10.1126/science.7545954

3. Reeves MD, Yawitch TM, van der Merwe NC, van den Berg HJ, Dreyer G, van Rensburg EJ. Localization of a Breast Cancer Susceptibility Gene, BRCA2, to Chromosome 13q12-13. Science (1994) 265(5181):2088-90. doi: 10.1126/ science. 8091231

4. Zhang B, Fackenthal JD, Niu Q, Huo D, Sveen WE, DeMarco T, et al. BRCA1 Mutations in South African Breast and/or Ovarian Cancer Families: Evidence of a Novel Founder Mutation in Afrikaner Families. Int J Cancer (2004) 110 (5):677-82. doi: 10.1002/ijc.20186

5. Zhang B, Fackenthal JD, Niu Q, Huo D, Sveen WE, DeMarco T, et al. Evidence for an Ancient BRCA1 Mutation in Breast Cancer Patients of Yoruban Ancestry. Fam Cancer (2009) 8(1):15-22. doi: 10.1007/s10689-0089205-9

6. Ndiaye R, Ndiaye R, Diop JPD, Bourdon-Huguenin V, Dem A, Diouf D, et al. Evidence for an Ancient BRCA1 Pathogenic Variant in Inherited Breast Cancer Patients From Senegal. NPJ Genom Med (2020) 5:8. doi: 10.1038/ s41525-020-0114-7

7. Mefford HC, Baumbach L, Panguluri RC, Whitfield-Broome C, Szabo C, Smith S, et al. Evidence for a BRCA1 Founder Mutation in Families of West African Ancestry. Am J Hum Genet (1999) 65(2):575-8. doi: 10.1086/302511

8. Stoppa-Lyonnet D, Laurent-Puig P, Essioux L, Pages S, Ithier G, Ligot L, et al. BRCA1 Sequence Variations in 160 Individuals Referred to a Breast/Ovarian Family Cancer Clinic. Institut Curie Breast Cancer Group. Am J Hum Genet (1997) 60(5):1021-30.

9. Abugattas J, Llacuachaqui M, Allende YS, Velasquez AA, Velarde R, Cotrina J, et al. Prevalence of BRCA1 and BRCA2 Mutations in Unselected Breast Cancer Patients From Peru. Clin Genet (2015) 88(4):371-5. doi: 10.1111/ cge. 12505

10. Villarreal-Garza C, Weitzel JN, Llacuachaqui M, Sifuentes E, MagallanesHoyos MC, Gallardo L, et al. The Prevalence of BRCA1 and BRCA2 Mutations Among Young Mexican Women With Triple-Negative Breast Cancer. Breast Cancer Res Treat (2015) 150(2):389-94. doi: 10.1007/s10549015-3312-8

11. Donenberg T, Lunn J, Curling D, Turnquest T, Krill-Jackson E, Royer R, et al. A High Prevalence of BRCA1 Mutations Among Breast Cancer Patients From the Bahamas. Breast Cancer Res Treat (2011) 125(2):591-6. doi: 10.1007/ s10549-010-1156-9

12. Weitzel JN, Lagos V, Blazer KR, Nelson R, Ricker C, Herzog J, et al. Prevalence of BRCA Mutations and Founder Effect in High Risk Hispanic Families. Cancer Epidemiol Biomarkers Prev (2005) 14(7):1666-71. doi: 10.1158/10559965.EPI-05-0072

13. Dutil J, Golubeva VA, Pacheco-Torres AL, Diaz-Zabala HJ, Matta JL, Monteiro AN. The Spectrum of BRCA1 and BRCA2 Alleles in Latin America and the Caribbean: A Clinical Perspective. Breast Cancer Res Treat (2015) 154(3):441-53. doi: 10.1007/s10549-015-3629-3

14. Akbari MR, Donenberg T, Lunn J, Curling D, Turnquest T, Krill-Jackson E, et al. The Spectrum of BRCA1 and BRCA2 Mutations in Breast Cancer Patients in the Bahamas. Clin Genet (2014) 85(1):64-7. doi: 10.1111/cge.12132

15. Rebbeck TR, Friebel TM, Friedman E, Hamann U, Huo D, Kwong A, et al. Mutational Spectrum in a Worldwide Study of 29,700 Families With BRCA1 or BRCA2 Mutations. Hum Mutat (2018) 39(5):593-620. doi: 10.1002/ humu. 23406

16. Olopade OI, Fackenthal JD, Dunston G, Tainsky MA, Collins F, WhitfieldBroome C. Breast Cancer Genetics in African Americans. Cancer (2003) 97(1 Suppl):236-45. doi: 10.1002/cncr.11019

17. Gao Q, Tomlinson G, Das S, Cummings S, Sveen L, Fackenthal J, et al. Prevalence of BRCA1 and BRCA2 Mutations Among Clinic Based African American Families With Breast Cancer. Hum Genet (2000) 107(2):186-91. doi: $10.1007 /$ s004390000290
18. Palmer JR, Polley EC, Hu C, John EM, Haiman C, Hart SN, et al. Contribution of Germline Predisposition Gene Mutations to Breast Cancer Risk in African American Women. J Natl Cancer Inst (2020) 112(12):1213-21. doi: 10.1002/ humu. 2304

19. Rummel SK, Lovejoy L, Shriver CD, Ellsworth RE. Contribution of Germline Mutations in Cancer Predisposition Genes to Tumor Etiology in Young Women Diagnosed With Invasive Breast Cancer. Breast Cancer Res Treat (2017) 164(3):593-601. doi: 10.1007/s10549-017-4291-8

20. Pal T, Bonner D, Cragun D, Monteiro ANA, Phelan C, Servais L, et al. A High Frequency Ofbrcamutations in Young Black Women With Breast Cancer Residing in Florida. Cancer (2015) 121(23):4173-80. doi: 10.1002/cncr.29645

21. Lynce F, Smith KL, Stein J, DeMarco T, Wang Y, Wang H, et al. Deleterious BRCA1/2 Mutations in an Urban Population of Black Women. Breast Cancer Res Treat (2015) 153(1):201-9. doi: 10.1007/s10549-015-3527-8

22. Churpek JE, Walsh T, Zheng Y, Moton Z, Thornton AM, Lee MK, et al. Inherited Predisposition to Breast Cancer Among African American Women. Breast Cancer Res Treat (2014) 149(1):31-9. doi: 10.1007/ s10549-014-3195-0

23. Rummel S, Varner E, Shriver CD, Ellsworth RE. Evaluation of BRCA1 Mutations in an Unselected Patient Population With Triple-Negative Breast Cancer. Breast Cancer Res Treat (2012) 137(1):119-25. doi: 10.1007/s10549$012-2348-2$

24. Litton JK, Ready K, Chen H, Gutierrez-Barrera A, Etzel CJ, Meric-Bernstam F, et al. Earlier Age of Onset Ofbrcamutation-Related Cancers in Subsequent Generations. Cancer (2012) 118(2):321-5. doi: 10.1002/cncr.26284

25. John EM, Miron A, Gong G, Phipps AI, Felberg A, Li FP, et al. Prevalence of Pathogenic BRCA1 Mutation Carriers in 5 US Racial/Ethnic Groups. JAMA (2007) 298(24):2869. doi: 10.1001/jama.298.24.2869

26. Hall MJ, Reid JE, Burbidge LA, Pruss D, Deffenbaugh AM, Frye C, et al. BRCA1 and BRCA2 Mutations in Women of Different Ethnicities Undergoing Testing for Hereditary Breast-Ovarian Cancer. Cancer (2009) 115(10):2222-33. doi: $10.1002 / \mathrm{cncr} .24200$

27. Nanda R, Schumm LP, Cummings S, Fackenthal JD, Sveen L, Ademuyiwa F, et al. Genetic Testing in an Ethnically Diverse Cohort of High-Risk Women. JAMA (2005) 294(15):1925. doi: 10.1001/jama.294.15.1925

28. Zhang J, Fackenthal JD, Zheng Y, Huo D, Hou N, Niu Q, et al. Recurrent BRCA1 and BRCA2 Mutations in Breast Cancer Patients of African Ancestry. Breast Cancer Res Treat (2012) 134(2):889-94. doi: 10.1007/ s10549-012-2136-z

29. Pal T, Permuth-Wey J, Holtje T, Sutphen R. BRCA1 and BRCA2 Mutations in a Study of African American Breast Cancer Patients. Cancer Epidemiol Biomarkers Prev (2004) 13(11 Pt 1):1794.

30. Buleje J, Guevara-Fujita M, Acosta O, Huaman FDP, Danos P, Murillo A, et al. Mutational Analysis Ofbrcalandbrca2genes in Peruvian Families With Hereditary Breast and Ovarian Cancer. Mol Genet Genomic Med (2017) 5 (5):481-94. doi: 10.1002/mgg3.301

31. Friebel TM, Andrulis IL, Balmana J, Blanco AM, Couch FJ, Daly MB, et al. BRCA1 and BRCA2 Pathogenic Sequence Variants in Women of African Origin or Ancestry. Hum Mutat (2019) 40(10):1781-96. doi: 10.1002/ humu. 23804

32. Quiles F, Teule A, Martinussen Tandstad N, Feliubadalo L, Tornero E, Del Valle J, et al. Identification of a Founder BRCA1 Mutation in the Moroccan Population. Clin Genet (2016) 90(4):361-5. doi: 10.1111/cge.12747

33. Ibrahim SS, Hafez EE, Hashishe MM. Presymptomatic Breast Cancer in Egypt: Role of BRCA1 and BRCA2 Tumor Suppressor Genes Mutations Detection. J Exp Clin Cancer Res (2010) 29:82. doi: 10.1186/1756-9966-29-82

34. Zoure AA, Slaoui M, Bambara HA, Sawadogo AY, Compaore TR, Ouedraogo NLM, et al. BRCA1 C.68_69delAG (Exon2), C.181t $>$ G (Exon5), C.798_799delTT and 943ins10 (Exon11) Mutations in Burkina Faso. J Public Health Afr (2018) 9(1):663.

Conflict of Interest: The authors declare that the research was conducted in the absence of any commercial or financial relationships that could be construed as a potential conflict of interest.

Publisher's Note: All claims expressed in this article are solely those of the authors and do not necessarily represent those of their affiliated organizations, or those of 
the publisher, the editors and the reviewers. Any product that may be evaluated in this article, or claim that may be made by its manufacturer, is not guaranteed or endorsed by the publisher.

Copyright (C) 2022 Diop, Sène, Dia, Ba, Mbacke, Ly, Sarr, Diouf, Ka, Mbengue, Gueye, Diop, Sylla Niang, Gueye, Lopez Sall, Dem, Cisse, Dieye and Ndiaye. This is an open- access article distributed under the terms of the Creative Commons Attribution License (CC BY). The use, distribution or reproduction in other forums is permitted, provided the original author(s) and the copyright owner(s) are credited and that the original publication in this journal is cited, in accordance with accepted academic practice. No use, distribution or reproduction is permitted which does not comply with these terms. 